\title{
Self-learning of Information Literacy Competencies in Higher Education: The Perspective of Social Sciences Students
}

\section{Maria Pinto, Rosaura Fernández-Pascual, and Francisco Javier García Marco}

Preference for autonomous versus directed learning for the acquisition of information competencies (ICs) was analyzed among undergraduate social science students according to gender, degree program, belief in importance, and self-efficacy. Data were gathered using the IL-HUMASS (Information Literacy Humanities Social Sciences) online survey from students at five public Spanish universities enrolled in audiovisual communication, education, information science, pedagogy, journalism, psychology, social work, and tourism undergraduate programs during the 2013-2014 academic year. Mann-Whitney $U$, Kruskal-Wallis, and chi-square tests, as well as discriminant analysis, were performed. The results revealed a higher preference for the directed learning style in the four IL competency categories: searching, evaluation, processing, and communication-dissemination. Audiovisual communication, education, and journalism students showed a predilection for autonomous learning, whereas information science and psychology students preferred directed learning. Higher scores in belief in importance correlated with a greater preference for autonomous learning. In contrast, higher levels of self-efficacy were associated with a greater preference for directed learning.

\section{Introduction}

Though a difficult quest, ${ }^{1}$ science is ultimately about finding general laws and theories that fully describe, explain, and predict the evidence in a field of interest. Individual studies confirm, question, or falsify laws and theories, which are therefore corroborated, corrected, or abandoned. In the same way, scientific approaches to information literacy (IL) should ideally try to find laws and develop theoretical models that can be applied to every case in the field of study, and, thereafter, try to confirm or put them into question. So, initial efforts in the field were devoted to proposing models for teaching information competency that could be applied

Maria Pinto is on the Faculty of Information Science and Rosaura Fernández-Pascual is Associate Professor in the Department of Quantitative Methods for Economics and Enterprise, both at the University of Granada; email: mpinto@ugr.es, rpascual@ugr.es. Francisco Javier García Marco is Professor in the Department of Information and Library Science at the University of Zaragoza; email: jgarcia@unizar.es. This research is part of the national RED Project "Innovación y formación en competencias informacionales de profesores y estudiantes universitarios de ciencias sociales" (CSO2016-80147-R), financed by MINECO. 
to any learner who should become information literate. A general model of this type is needed both to establish a basic paradigm of intervention and to organize the information about the basic process of information literacy with the aim of providing a conceptual structure on which a synthesis of the discipline can be developed and from which practical interventions can be programmed, scheduled, and assessed.

One of the best and well-known IL models, provided by Carol Kuhlthau, is now almost thirty years old. ${ }^{2}$ It shows the role of the different psychological layers (affective, cognitive, and behavioral) in the search information process and serves as a general and complete model for IL intervention. These theoretical models were followed by normative documents in the field of information competency development, particularly those by the Association of College and Research Libraries. ${ }^{3}$ This normative effort was grounded in several decades of theoretical and empirical work in developing models of information competency acquisition. Besides this practical, normative effort, the last two decades of research have been devoted to incorporate the impact of the information technologies revolution; to amass evidence in different fields of practice and different environments; to further validate and develop the general IL models; and to enrich these models with the consideration of new relevant explicative variables.

Due to the scarcity of research on Social Sciences (SS) students' views regarding information literacy, it is of interest to explore their concept of the topic to gain a better understanding of the process of learning IL competencies. Restricted to library and information science (LIS) students, Head and Eisenberg ${ }^{4}$ concluded that the kind of information resource used is an essential factor for understanding the subjective characteristics of students in relation to their information competencies. Results of the present research reveal that learning styles have much to say in the processes of improving SS students' IL competencies. This indeed agrees with the markedly phenomenographic suggestion raised by Bruce, Edwards, and Lupton: ${ }^{5}$ "teachers need to assist students in developing new and more complex ways of experiencing Information Literacy."

The research presented in this article tries to build on these lines of research, by incorporating the information revolution, gathering further evidence, and enriching IL models with new variables. Particularly, its general aim is to identify what learning styles are used by SS students for the acquisition of information competencies (ICs) in relation to their specific programs of study and several social and psychological characteristics of the students. Learning styles refers mainly to the dichotomy "autonomous versus directed learning," as a result of both the students' attitudes and abilities (learning readiness) and of its framing by the educative environment, such as if the information competency categories are considered in the curriculum or they are left to students' self-learning.

The main research goals are the following:

R1: Provide an overview of the SS students' learning styles by the four information competency categories (searching, assessing, processing, and communicating information) to gain a better understanding of their general behavior and the influence of gender and degree program on such competencies.

R2: Determine which IL categories exhibit behavioral differences.

R3: Analyze the learning styles by the second-level IL competencies, providing a more precise and in-depth exploration of the first goal, particularly in relation to the different disciplines that were surveyed. Do significant differences arise among SS students of the various degree programs? If so, in which IL competencies do the SS students show different preferences? 
R4: Determine if there is some kind of relationship between the SS students' learning styles and their reported levels of belief in importance (BI) and self-efficacy (SE) with regard to IL competencies.

R5: Explore in depth the SS students' tendencies toward preferred learning styles related to IL competencies according to their degree programs and perceptions of BI and SE by means of a discriminant model.

All in all, the potential benefits of this study to scholarship and practice are, among others, that students can be involved in the processes of attaining their own IL competencies; that each IL competence can be better achieved if it adapts to the learning style expressed by the student; or that knowing their preferences in terms of learning styles can motivate a greater involvement of students in their own learning.

\section{Literature Review}

The two scholarly pillars of this study are the constructivist and the phenomenographic approaches to IL. Both are focused not only on the common, general aspects of the IL experience, but also on the features that make it special, such as the social and personal variations in background, processing, and experience. Regarding the role of differential traits in IL development, teachers and students may have different social backgrounds, genetic traits, and personal experiences; they may therefore differ in their IL motivations and competencies. While teachers place different emphasis on topics and methodologies, students take different approaches toward mastering information competency. This is a common experience in teaching that, as expected, has also been consistently referred to in the IL literature. ${ }^{6}$ In consonance with the focus on social and individual differences, a precise definition of IL is not pursued here; rather, IL is approached as a socially and scientifically evolving topic, in permanent construction, attending to the social and psychological characteristics that are emphasized.

Regarding the social dimension of IL, the first thing that draws the researcher's attention is its cross-disciplinary nature and its ubiquity in all the fields of human activity, well glossed by IL scholars. According to Lloyd" "the enactment of information literacy emerges through the meaningful activities people engage with in relation to the creation, dissemination, access and use of information within any particular setting." Another characteristic to emphasize on IL is its marked social condition. As stated by Walton and Cleland, "robust theoretical works and empirical studies supported by extensive information behavior research on the cognitive, metacognitive, affective and social processes which underpin IL indicate that IL is less of an individualized activity and more social in nature." IL's growing contextual dependence should also be emphasized, which further opens the field to the study of social differential traits. For Limberg et al., " "studies tend to abandon the idea of information literacy seen as generic skills applicable across disciplines and contexts in favor of a view of information literacy as a social practice shaped by the culture and context in which it is embedded." Particularly, sociological sources of individual variability that have become the target of growing research interest have been contextual needs, ${ }^{10}$ gender, ${ }^{11}$ educational background, ${ }^{12}$ occupational status, ${ }^{13}$ and even culture and nationality. ${ }^{14}$

Besides IL social dimension, its psychological dimension has received careful attention in the scholarly literature, with phenomenography offering multiple contributions ${ }^{15}$ on the basis of variations in experience as the main focus of approach and analysis. ${ }^{16}$ Psychological variables in which students differ have been the subject of a substantial amount of research in the field of 
IL. In this regard, students' self-concept of their IL competency, and self-efficacy in particular, is one of the variables that has attracted considerable attention. This is due to its significant and positive correlation with IL competency, its effects on motivation, and its importance for studying the congruence between objective and subjective measures of IL competency. ${ }^{17}$ More comprehensibly, Malliari, Korobili, and Zapounidou ${ }^{18}$ conducted a very interesting research on the information-seeking behavior of Macedonia University undergraduates, taking into account a complete set of personality characteristics, not only the usual sociological ones.

In recent decades, differential psychologists have shown an increased interest in the interaction between subjects and their contexts in an attempt to balance the need to recognize diversity while pursuing explanatory principles. The concepts of learning strategies and styles have become central in these efforts. The presence of various individual approaches to learning and thinking has been of interest to educational psychologists for many years. ${ }^{19}$ In this effort, a number of interesting constructs have arisen, mainly around the concept of cognitive styles that imply the existence of stable and consistent long-term personality traits, dispositions, or preferences toward the acquisition of knowledge. Over the years, the earlier, simpler models of cognitive styles have evolved to become more complex. For example, the difference between deep and superficial processing ${ }^{20}$ or a more recent and complex model considering four categories: converger, diverger, assimilator, and accommodator. ${ }^{21}$ Both models have been extensively used in IL theory and practice. ${ }^{22}$ At the other extreme lies what is likely the most elaborated effort: that of Sternberg, ${ }^{23}$ who developed a very complex model to explain individual differences in cognition based on the metaphor of types of government. Later, the Sternberg's taxonomy and the previous research of other authors into two distinct types of thinking styles were synthesized: holistic and analytic thinking. ${ }^{24}$ More recently, Zhang, Sternberg, and Fan ${ }^{25}$ have proposed the "intellectual style" construct, "an encompassing term for such constructs as learning style, teaching style, teaching approach, and thinking style, which refers to one's preferred way of processing information."

The impact of personality dimensions on information seeking has been studied for years in the field of information behavior. ${ }^{26}$ As stated by Markless and Streatfield, ${ }^{27}$ "schools that take information literacy seriously usually link this to other pedagogic developments such as active learning and problem-solving. In this context, emphasis is placed on people's preferred learning styles being taken into account when planning and delivering sessions or learning programmes." Diehm and Lupton maintain that ${ }^{28}$ "research on learning styles and approaches can be used by faculty and librarians to inform information literacy education." Palmer ${ }^{29}$ provided a thorough, critical review on the application of learning styles in IL. In her review, she acknowledges the practical and theoretical importance of learning styles, but she advises against taking a highly controversial corpus of knowledge as a quick receipt for teaching IL and calls for research and reflection: "the problems with learning styles need to be acknowledged and considered much more extensively in the information literacy literature."

The autonomous, self-directed, or independent learning style has been mainly studied by Webber, Boon, and Johnston, who concluded that ${ }^{30}$ "becoming confident autonomous learners and critical thinkers was clearly a goal for both students and staff." For McGuiness, ${ }^{31}$ "the idea of individual responsibility for self-development and learning is a powerful one, and is viewed by faculty as a strong indicator of whether a student will benefit from their educational experience as a whole, not just in the IL arena." Coonan observed that ${ }^{32}$ "the need for students to become informed and autonomous, capable of adapting to new information 
contexts, is greater than ever before." In the same way, Candy ${ }^{33}$ stresses the importance, and future, of self-directed learning within the context of lifelong learning: "since we are currently experiencing an unprecedented level and pace of change on a global scale, it is plausible to expect the demands of a changing world to lead to greater amounts of self-directed learning."

The IL-HUMASS test on information literacy, which served as the main source of data for this study, is precisely aimed at self-assessing IL among undergraduates and designed to provide insight into their perceptions and expectations about IL-related aspects. ${ }^{34}$ Of the countless sources of variability that can be found within IL from the phenomenographic perspective, this research has focused its attention on only three of them, which are precisely those present in the IL-HUMASS questionnaire. There are two (BI: belief in importance of IL competencies and SE: self-efficacy) that relate to students' affections; the third (LS) relates to their learning style. Based on the same test, yet applied to teaching staff, Pinto ${ }^{35}$ concluded that "a deeper understanding of faculty members' relationship with IL is required, especially from the point of view of their subjective values, perceptions and opinions." In this same line, Pinto and Fernandez-Pascual ${ }^{36}$ have carried out, among Social Sciences students, a more indepth research on the affective sources of variability within IL-HUMASS:

The belief in importance (BIM) concept, which some educators identify with the idea of motivation, refers to the rating of the importance of certain competencies on the part of students. Self-Efficacy (SE) seems to be a more sophisticated idea, often defined as people's beliefs about their capabilities to produce the designated levels of performance. SE determines how people feel, think, motivate themselves, and behave (p.1).

\section{Methodology}

Following the constructivist-phenomenographic approach, ${ }^{37}$ this paper focuses on one of the sources of variation with regard to the acquisition of IL competency: autonomous learning and the contexts in which it develops. In the last part of the previous literature review, the capability to develop a learning style was considered a competency based on a long-term characteristic of the person, namely a personality trait: that is, a basic tendency toward selfdirected learning that may be a predictor of academic success. The present paper intends to analyze this key competence and its main dimensions (search, evaluation, processing, and communication-dissemination of information) by relating it to four variables that have traditionally been studied in IL, closely linked to students' personal features. Two are objective (gender and academic discipline) and two students' subjective, or psychological, constructs (BI: belief in importance and SE: self/efficacy). With the results, a successful IL strategy that effectively addresses individual variations in SS students' experiences could be designed.

Data were gathered using the IL-HUMASS online survey, web-based format, and an attitudinal test considering three dimensions: motivation, self-efficacy, and favorite source of learning. ${ }^{38}$ Motivation is defined as the importance given by students to the competencies for academic progress. Self-efficacy refers to their estimated levels of skill in the competencies. Students are asked to indicate their assessment of the competencies by marking their answers on a scale from 1 (low competency) to 9 (excellent competency) for each dimension. Favorite source of learning allows students to select among a set of possible sources of learning: class, 
library, courses, self-learning, and others.

The 26 items in the survey are clustered in four categories:

- Searching:

1. using printed sources of information;

2. entering and using automated catalogues;

3. consulting and using electronic sources of printed information;

4. using electronic sources of secondary information;

5. knowing the terminology of your subject;

6. searching for and retrieving internet information;

7. using informal electronic sources of information;

8. knowing information search strategies.

- Evaluation:

1. assessing the quality of information resources;

2. recognizing the author's ideas within the text;

3. knowing the typology of scientific information sources;

4. determining whether an information resource is updated;

5. knowing the most relevant authors and institutions within your subject area.

- Processing:

1. systematizing information and abstracting;

2. recognizing text structure;

3. using database managers;

4. using bibliographic reference managers;

5. handling statistical programs and spreadsheets;

6. installing computer programs.

- Communication-Dissemination:

1. communicating in public;

2. communicating in other languages;

3. writing a document;

4. knowing the code of ethics in your academic/professional field;

5. knowing the laws on the use of information and intellectual property;

6. creating academic presentations;

7. disseminating information on the internet.

The questionnaire has been widely validated in previous studies, which makes this scale highly consistent and reliable. ${ }^{39}$ Taking into account that there are other recent studies related to IL-HUMASS ${ }^{40}$ this research pays attention to the preferred sources of learning from a set of possible learning scenarios with regard to IL competencies and skills, including classroom, library, courses, and autonomous learning. Throughout the analysis, a distinction is made between directed (class, library, courses) and self-directed (autonomous) learning styles.

The population under study was drawn from SS students at five public Spanish universities: University Complutense of Madrid, University of Granada, University Jaume I of Castellón, University of Malaga, and University of Murcia. The students were enrolled in undergraduate degree programs in the social sciences related to audiovisual communication, education, information science, pedagogy, journalism, psychology, social work, and tourism. The sample was selected from third- and fourth-year students enrolled in compulsory subjects during the 2013-2014 academic years. A stratified sample design with proportional alloca- 
tion was used considering three strata: university, degree program, and course. The sample size allowed calculating the minimum number of participants to estimate with an accuracy of 0.5 points the average values of BI and SE. Finally, the sample sizes in each stratum were increased by 20 percent to overcome the possible lack of response.

The method employed ensured that the gathered information was representative, providing a considerable level of consistency for drawing inferences. Samples included 1.575 valid surveys, which were distributed among the eight degree programs (see table 1).

\begin{tabular}{|l|c|c|c|c|c|c|c|}
\hline \multicolumn{7}{|c|}{ TABLE 1 } \\
\hline & \multicolumn{7}{|c|}{ Students per University } \\
\hline & $\begin{array}{c}\text { Complutense } \\
\text { Madrid }\end{array}$ & Granada & $\begin{array}{c}\text { Jaume I } \\
\text { Castellón }\end{array}$ & Malaga & Murcia & Total & $\%$ \\
\hline Degree Program & 33 & 26 & 29 & 82 & 28 & 198 & $13 \%$ \\
\hline 1. Audiovisual Communication & 24 & 166 & 55 & 42 & 83 & 370 & $23 \%$ \\
\hline 2. Education & 59 & 39 & 0 & 0 & 24 & 122 & $8 \%$ \\
\hline 3. Information Science & 15 & 45 & 1 & 22 & 30 & 113 & $7 \%$ \\
\hline 4. Pedagogy & 43 & 0 & 53 & 85 & 55 & 236 & $15 \%$ \\
\hline 5. Journalism & 35 & 131 & 27 & 11 & 19 & 223 & $14 \%$ \\
\hline 6. Psychology & 27 & 73 & 0 & 18 & 19 & 137 & $9 \%$ \\
\hline 7. Social Work & 30 & 67 & 23 & 36 & 20 & 176 & $11 \%$ \\
\hline 8. Tourism & 266 & 547 & 188 & 296 & 278 & 1,575 & \\
\hline & $17 \%$ & $35 \%$ & $12 \%$ & $19 \%$ & $18 \%$ & & \\
\hline
\end{tabular}

The distribution by gender and year of study is shown (see table 2). As can be observed, there is a clear predominance of women compared to men.

To address the study's goals, descriptive, inferential, and multivariate statistical techniques adapted to the nature of the survey's ordinal variables were employed using SPSS software. As normality was not fulfilled, the use of nonparametric techniques was required. This was especially important in trying to respond to the first, second, and third goals, such as in which categories and IL competencies the students were showing different preferences in relation to their gender and the degree programs they were studying. Three nonparametric techniques were employed: a) the Mann-Whitney $U$ test was selected and performed

\begin{tabular}{|l|l|c|c|c|}
\hline \multicolumn{5}{|c|}{ TABLE 2} \\
Sample Distribution by Gender and \\
Year of Study \\
\hline Gender \\
\hline Male & Year & 3rd & 333 & $66.6 \%$ \\
\hline & & 4 th & 167 & $33.4 \%$ \\
\hline & & Total & $\mathbf{5 0 0}$ & $100 \%$ \\
\hline Female & Year & 3rd & 768 & $71.4 \%$ \\
\hline & & 4th & 307 & $28.6 \%$ \\
\hline & & Total & $\mathbf{1 , 0 7 5}$ & $100 \%$ \\
\hline
\end{tabular}
to compare the differences between two independent groups (male/female or third/ fourth year); b) the Kruskal-Wallis test (an alternative to ANOVA) was performed to determine if there were any statistically significant differences between the different degree programs; ${ }^{41}$ and c) the chi-square test was applied to determine if there was some kind of relationship between learning styles and the BI or SE values with regard to IL competencies (R4). 
Finally, a discriminant analysis was carried out to give response to R5. This multivariate technique for classification is useful to construct a predictive model based on certain observed characteristics, as well as to forecast the group to which an observation belongs. ${ }^{42}$ In this study, the focus is on successfully predicting the preferred learning style of the IL competencies based on the degree program and the reported BI and SE values.

\section{Results and Discussion}

The first issue to be explored is the preferred learning style of SS students. Outcomes reveal a preference for directed learning over autonomous learning not only concerning IL categories but also competencies. Subsequently, the relationship of these styles with the two affective dimensions-B: belief in importance and SE: self-efficacy - on the same set of competencies is explored. Finally, the discriminant model that allows predicting the style of learning is depicted. This section ends with a summary of the results obtained.

In regard to the preferred learning styles for achieving IL competency categories (R1), the results reveal a slight preference for directed learning over autonomous learning. Restricted to directed learning, the preference is higher in the categories of searching and evaluation. Conversely, within self-directed or autonomous learning, the greater preference is for the categories of processing and communication-diffusion of information (see table 3).

\begin{tabular}{|l|c|c|c|}
\hline \multicolumn{4}{|c|}{ TABLE 3 } \\
\hline \\
\hline Sreferred Learning Styles Regarding the Four Competency Categories \\
\hline Evarching & Autonomous Learning & Directed Learning & $P$-value \\
\hline Processing & $43.4 \%$ & $56.6 \%$ & 0.0000 \\
\hline Communication-Dissemination & $40.2 \%$ & $59.8 \%$ & 0.0000 \\
\hline Global & $46.9 \%$ & $53.1 \%$ & 0.0138 \\
\hline
\end{tabular}

Concerning autonomous learning preferences by both genders, significant differences were found only in the processing category (Mann-Whitney $U$ test, $P<0.05$ ). In all categories, men are slightly more prone to self-learning (see table 4).

Regarding the degree programs, audiovisual communication, education, and journalism students show a predilection for autonomous learning, whereas information science and psychology students prefer the directed learning style for IL categories (see figure 1).

\begin{tabular}{|l|c|c|c|}
\hline \multicolumn{4}{|c|}{ TABLE 4 } \\
\hline Preferences within Autonomous Learning by Category and Gender \\
\hline Category & Male & Female & $P$-value \\
\hline Searching & $44.40 \%$ & $42.97 \%$ & 0.6061 \\
\hline Evaluation & $40.44 \%$ & $40.00 \%$ & 0.8816 \\
\hline Processing & $49.00 \%$ & $46.06 \%$ & $0.0276^{*}$ \\
\hline Communication-Dissemination & $45.57 \%$ & $43.54 \%$ & 0.4517 \\
\hline * Significant differences, Mann-Whitney U test, $\mathrm{p}<0.05$ & \\
\hline
\end{tabular}


However, these results do not indicate the obligation to adapt the learning of IL competencies to the preferred learning style. But it seems likely that students show a greater preference for directed learning when they have had a successful experience in the context of their instruction, as it happens in the case of information science and psychology students within the processing category. Outcomes reveal that the way of experiencing IL is related both to the academic degree and to IL competency categories.

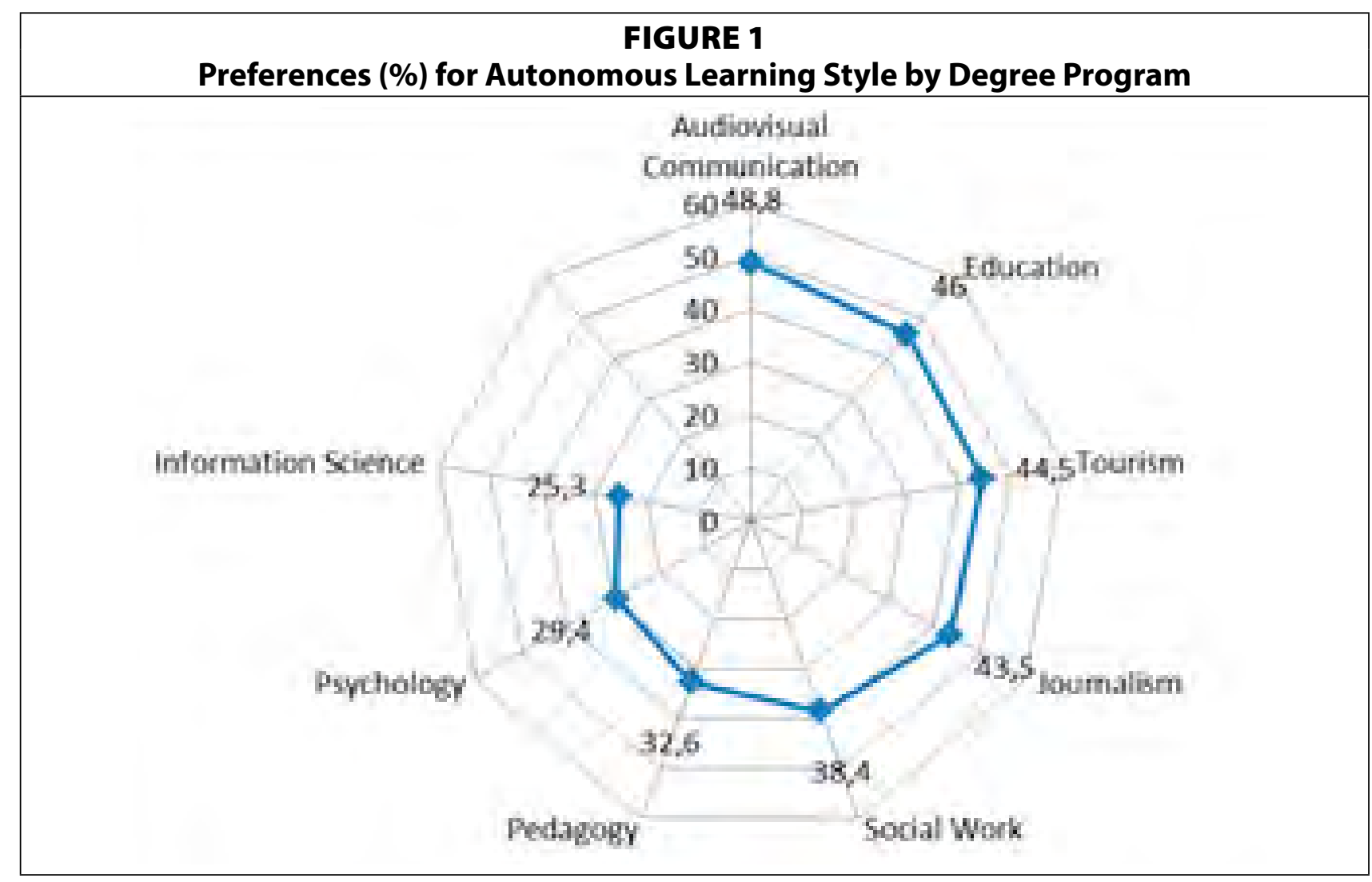

On the style of learning by IL competency (R3), the results show that most students prefer autonomous learning for seven competencies, while directed learning is preferred for the remaining 19. In competencies c3: electronic sources of primary information and c20: communication in public, these percentages do not present statistically significant differences (binomial test, $P>0.05$ ), since the proportions of students who go for an autonomous or directed learning styles are similar (see table 5).

In regard to gender, the greater preference for the autonomous style is shaded in gray (see table 6). Significant differences regarding gender were found in these competencies: c4: using electronic sources of secondary information, c5: knowing the terminology of your subject, c16: using database managers, c18: handling statistical programs and spreadsheets, and c19: installing computer programs (Mann-Whitney $\mathrm{U}$ test, $P<0.05$ ). This result is in line with the slight preference for analytical-mathematical thinking in males related to a greater use of visuospatial strategies in their socializing experiences. ${ }^{43}$

To better understand the influence of degree program on IL learning styles, nonparametric methods were used. The analysis was performed on the 26 IL competencies included in the ILHUMASS test and the eight degree programs. Findings revealed different behaviors related to 


\begin{tabular}{|c|c|c|c|c|}
\hline \multicolumn{5}{|c|}{$\begin{array}{c}\text { TABLE } 5 \\
\text { Autonomous Versus Directed Learning Style; Preferences by Competency; P-values of } \\
\text { Binomial Test }\end{array}$} \\
\hline $\begin{array}{l}\text { Learning } \\
\text { Style }\end{array}$ & Categories & Competencies & $\%$ & $P$-value \\
\hline \multirow[t]{7}{*}{ Autonomous } & \multirow[t]{2}{*}{ Searching } & $\begin{array}{l}\text { c6 searching for and retrieving information on the } \\
\text { Internet (advanced searches) }\end{array}$ & 67.3 & 0.000 \\
\hline & & $\begin{array}{l}\text { c7 using informal electronic sources of information } \\
\text { (blogs, etc.) }\end{array}$ & 73.8 & 0.000 \\
\hline & Evaluation & $\begin{array}{l}\text { c12 determining whether an information resource is } \\
\text { updated }\end{array}$ & 58.4 & 0.000 \\
\hline & \multirow[t]{2}{*}{ Processing } & c14 schematizing and abstracting information & 64.4 & 0.000 \\
\hline & & c19 installing computer programs & 78.9 & 0.000 \\
\hline & \multirow{2}{*}{$\begin{array}{l}\text { Communication- } \\
\text { Dissemination }\end{array}$} & c25 creating academic presentations (PowerPoint, etc.) & 66.3 & 0.000 \\
\hline & & $\begin{array}{l}\text { c26 disseminating information on the Internet (webs, } \\
\text { blogs, etc.) }\end{array}$ & 77.5 & 0.000 \\
\hline \multirow[t]{19}{*}{ Directed } & \multirow[t]{6}{*}{ Searching } & $\begin{array}{l}\text { c1 using printed sources of information (books, papers, } \\
\text { etc.) }\end{array}$ & 62.5 & 0.000 \\
\hline & & c2 entering and using automated catalogs & 67.5 & 0.000 \\
\hline & & $\begin{array}{l}\text { c3 consulting and using electronic sources of primary } \\
\text { information }\end{array}$ & 51.3 & 0.844 \\
\hline & & $\begin{array}{l}\text { c4 using electronic sources of secondary information } \\
\text { (databases, etc.) }\end{array}$ & 70.9 & 0.000 \\
\hline & & c5 knowing the terminology of your subject & 85.1 & 0.000 \\
\hline & & c8 knowing information search strategies & 55.2 & 0.020 \\
\hline & \multirow[t]{4}{*}{ Evaluation } & c9 assessing the quality of information resources & 55.4 & 0.034 \\
\hline & & c10 recognizing the author's ideas within the text & 58.3 & 0.000 \\
\hline & & $\begin{array}{l}\text { c11 knowing the typology of scientific information } \\
\text { sources (theses, proceedings, etc.) }\end{array}$ & 68.3 & 0.000 \\
\hline & & $\begin{array}{l}\text { c13 knowing the most relevant authors and institutions } \\
\text { within your subject area }\end{array}$ & 75.9 & 0.000 \\
\hline & \multirow[t]{4}{*}{ Processing } & c15 recognizing the structure of a text & 63.6 & 0.000 \\
\hline & & c16 using database managers (Access, MySQL, etc.) & 62.8 & 0.000 \\
\hline & & $\begin{array}{l}\text { c17 using bibliographic reference managers (Endnote, } \\
\text { Reference Manager, etc.) }\end{array}$ & 59.2 & 0.002 \\
\hline & & $\begin{array}{l}\text { c18 handling statistical programs and spreadsheets } \\
\text { (SPSS, Excel, etc.) }\end{array}$ & 65.2 & 0.000 \\
\hline & \multirow{5}{*}{$\begin{array}{l}\text { Communication- } \\
\text { Dissemination }\end{array}$} & c20 communicating in public & 50.7 & 0.920 \\
\hline & & c21 communicating in other languages & 67.7 & 0.000 \\
\hline & & c22 writing a document (report, academic work, etc.) & 66.0 & 0.000 \\
\hline & & $\begin{array}{l}\text { c23 knowing the code of ethics in your academic/ } \\
\text { professional field }\end{array}$ & 77.1 & 0.000 \\
\hline & & $\begin{array}{l}\text { c24 knowing the laws on the use of information and } \\
\text { intellectual property }\end{array}$ & 70.9 & 0.000 \\
\hline
\end{tabular}




\begin{tabular}{|c|c|c|c|c|}
\hline \multicolumn{5}{|c|}{$\begin{array}{l}\text { TABLE } 6 \\
\text { Preference for the Autonomous Learning Style by Gender }\end{array}$} \\
\hline Categories & Competencies & Male & Female & $P$-value \\
\hline \multirow[t]{8}{*}{ Searching } & $\begin{array}{l}\text { c1 using printed sources of information (books, } \\
\text { papers, etc.) }\end{array}$ & 36.40 & 38.00 & 0.5462 \\
\hline & c2 entering and using automated catalogues & 33.40 & 32.10 & 0.6124 \\
\hline & $\begin{array}{l}\text { c3 consulting and using electronic sources of primary } \\
\text { information }\end{array}$ & 51.40 & 47.10 & 0.1162 \\
\hline & $\begin{array}{l}\text { c4 using electronic sources of secondary information } \\
\text { (databases, etc.) }\end{array}$ & 33.80 & 27.00 & $0.0063^{*}$ \\
\hline & c5 knowing the terminology of your subject & 19.00 & 13.00 & $0.0021^{*}$ \\
\hline & $\begin{array}{l}\text { c6 searching for and retrieving information on the } \\
\text { Internet (advanced searches, etc.) }\end{array}$ & 66.80 & 67.50 & 0.7853 \\
\hline & $\begin{array}{l}\text { c7 using informal electronic sources of information } \\
\text { (blogs, etc.) }\end{array}$ & 71.40 & 73.40 & 0.4122 \\
\hline & c8 knowing information search strategies & 43.00 & 45.70 & 0.3216 \\
\hline \multirow[t]{5}{*}{ Evaluation } & c9 assessing the quality of information resources & 42.60 & 45.80 & 0.2400 \\
\hline & c10 recognizing the author's ideas within the text & 43.60 & 40.70 & 0.2828 \\
\hline & $\begin{array}{l}\text { c11 knowing the typology of scientific information } \\
\text { (theses, proceedings, etc.) }\end{array}$ & 28.80 & 33.20 & 0.0843 \\
\hline & $\begin{array}{l}\text { c12 determining whether an information resource is } \\
\text { updated }\end{array}$ & 60.2 & 57.6 & 0.3354 \\
\hline & $\begin{array}{l}\text { c13 knowing the most relevant authors and } \\
\text { institutions within your subject area }\end{array}$ & 27 & 22.7 & 0.0665 \\
\hline \multirow[t]{6}{*}{ Processing } & c14 schematizing and abstracting information & 52.00 & 55.5 & 0.1995 \\
\hline & c15 recognizing text structure & 36 & 36.7 & 0.7906 \\
\hline & c16 using database managers (Access, MySQL, etc.) & 41.2 & 35.3 & $0.0258^{*}$ \\
\hline & $\begin{array}{l}\text { c17 using bibliographic reference managers (Endnote, } \\
\text { Reference Manager, etc.) }\end{array}$ & 41.4 & 40.6 & 0.7664 \\
\hline & $\begin{array}{l}\text { c18 handling statistical programs and spreadsheets } \\
\text { (SPSS, Excel, etc.) }\end{array}$ & 41.4 & 30.9 & $0.0000^{*}$ \\
\hline & c19 installing computer programs & 82 & 77.4 & $0.0394^{*}$ \\
\hline \multirow{7}{*}{$\begin{array}{l}\text { Communication- } \\
\text { Dissemination }\end{array}$} & c20 communicating in public & 50.4 & 48.8 & 0.6612 \\
\hline & c21 communicating in other languages & 34.6 & 31.2 & 0.1845 \\
\hline & c22 writing a document (report, academic work, etc.) & 36.2 & 32.9 & 0.2034 \\
\hline & $\begin{array}{l}\text { c23 knowing the code of ethics in your academic/ } \\
\text { professional field }\end{array}$ & 25.6 & 21.6 & 0.0823 \\
\hline & $\begin{array}{l}\text { c24 knowing the laws on the use of information and } \\
\text { intellectual property }\end{array}$ & 29.4 & 28.9 & 0.8407 \\
\hline & c25 creating academic presentations (PowerPoint, etc.) & 64.8 & 67.1 & 0.3742 \\
\hline & $\begin{array}{l}\text { c26 disseminating information on the Internet (webs, } \\
\text { blogs, etc.) }\end{array}$ & 78 & 77.2 & 0.7266 \\
\hline
\end{tabular}


the learning styles of the IL competencies depending on academic degree, except for cl: using printed information sources (Kruskal-Wallis test, $P=0.656>0.05),{ }^{44} \mathrm{c} 20$ : communicating in public $(P=0.073>0.05)$, and c22: writing a document $(P=0.372>0.05)$. These results provide further evidence that SS students are conditioned by the learning sources at their reach. There is a general tendency toward the directed learning style in all the degree programs, which has been quantified showing the degrees with a higher/lower trend (see tables 7-10 of the appendix).

As a general trend, students prefer directed learning for the 23 IL competencies in which significant differences were found by academic degree. The detailed statistical results are shown in tables $1 \mathrm{~A}-4 \mathrm{~A}$ of the appendix.

To address R4, the possible relationships between students' BI and SE levels and learning styles were analyzed. First, descriptive measures associated with the students' BI and SE values were calculated, distinguishing between autonomous and directed learning styles (see table 7). In this regard, students who prefer an autonomous learning style show higher BI levels, while students who prefer the directed style declare themselves to be more self-efficacious. It seems reasonable to think that students with higher BI and SE levels in some IL competencies, from the knowledge of their intrinsic characteristics, are more able to identify their preferred learning style. The authors agree with Dunn, Dunn, and Price ${ }^{45}$ and with Allinson and Hayes ${ }^{46}$ when asserting that the learning style may be the most important determinant of educational success.

\begin{tabular}{|l|c|c|c|c|c|c|c|c|}
\hline \multicolumn{8}{|c|}{ TABLE 7 } \\
Descriptive Measures of BI and SE for IL Competencies with Regard to Competency \\
Categories and Preferred Learning Styles \\
\hline Learning Style & \multicolumn{2}{|c|}{ Searching } & \multicolumn{2}{c|}{ Evaluation } & \multicolumn{2}{c|}{ Processing } & \multicolumn{2}{c|}{$\begin{array}{c}\text { Communication- } \\
\text { Dissemination }\end{array}$} \\
\hline Autonomous & BI & SE & BI & SE & BI & SE & BI & SE \\
\hline Mean & 7.55 & 6.54 & 7.81 & 6.61 & 7.41 & 6.22 & 8.14 & 6.78 \\
\hline SD & 0.92 & 1.14 & 0.96 & 1.11 & 1.01 & 1.20 & 0.76 & 1.03 \\
\hline & & & & & & & & \\
\hline Directed & BI & SE & BI & SE & BI & SE & BI & SE \\
\hline Mean & 7.49 & 6.70 & 7.78 & 6.73 & 7.39 & 6.39 & 8.12 & 6.82 \\
\hline SD & 1.00 & 1.13 & 1.07 & 1.08 & 1.36 & 1.13 & 0.99 & 1.02 \\
\hline
\end{tabular}

Outcomes are consistent with other research on tendencies for self-learning. A recent study showed that participants with Type I styles (that is to say, more creativity-generating, less structured, and cognitively more complex) had higher levels of university self-efficacy, while students with Type II styles (in other words, more norm-favoring, more structured, and cognitively more simplistic) displayed lower levels. ${ }^{47}$

In addition, the chi-square test of independence was performed to determine the existence of relationships between the levels of BI or SE and learning styles. To satisfy the validity conditions of the chi-square test for contingency tables (the expected value of each cell should be greater than 5), the BI and SE values were recoded into the following three levels: low (from 0 to 4.99), medium (from 5 to 6.99) and high (from 7 to 9). The results reveal some relationship between the levels of both BI and SE and the preferred learning style for most 
IL competencies (chi square, $P<0.05$ ). The only exceptions are 4 : using electronic sources of secondary information and c10: recognizing the author's ideas in the text, as the expected values of the chi-square test were not reached for these competencies.

Regarding the fifth goal, the most important contribution of this research is the possibility of discriminating between the styles (autonomous or directed) based on the reported BI and SE levels and the degree program (as some correlations between the levels of both BI and SE and the preferred learning style were found). To offer a better answer on this research question, a discriminant analysis was performed for each IL competency. This statistical technique permits predicting the students' preferred learning style. ${ }^{48}$ The discriminant analysis provides a classification scheme that allows the following: a) explaining the choice regarding the learning style of the students in the sample; and b) predicting the group to which a new student is most likely to belong, assuming that the BI and SE profiles and the degree program are known.

SPSS directly provides the predicted group membership for the whole sample (see table 8 for selected cases). These model files can be used to apply the model information to other data files for scoring/classification purposes: "export model information to the specified file in XML format." This knowledge allows teachers to modify or reinforce students' previous learning tendencies.

\begin{tabular}{|c|l|c|c|l|l|l|l|l|l|l|l|l|l|}
\hline \multicolumn{10}{|c|}{ How the Discriminant Model Works. Predicted Group Membership } \\
\hline $\begin{array}{c}\text { Id } \\
\text { Student }\end{array}$ & Degree & BI & SE & $\begin{array}{l}\text { Predicted } \\
\text { Group }\end{array}$ & BI & SE & $\begin{array}{l}\text { Predicted } \\
\text { Group }\end{array}$ & BI & SE & $\begin{array}{l}\text { Predicted } \\
\text { Group }\end{array}$ & BI & SE & $\begin{array}{l}\text { Predicted } \\
\text { Group }\end{array}$ \\
\hline 1 & Aud Comm & 9 & 4 & Autonomous & 7 & 5 & Autonomous & 9 & 6 & Directed & 8 & 7 & Directed \\
\hline 2 & Inf Science & 8 & 8 & Directed & 8 & 7 & Directed & 8 & 9 & Directed & 9 & 2 & Autonomous \\
\hline 3 & Journalism & 7 & 7 & Autonomous & 7 & 6 & Directed & 7 & 6 & Autonomous & 7 & 7 & Directed \\
\hline 4 & Psychology & 8 & 3 & Directed & 7 & 3 & Directed & 9 & 8 & Autonomous & 8 & 8 & Directed \\
\hline
\end{tabular}

More details on the discriminant analysis are included in the appendix. Specifically: a) the discriminant scores obtained by one information science student, with reported levels in $\mathrm{BI}$ and SE, are displayed in tables $5 \mathrm{~A}$ through $8 \mathrm{~A}$ in the appendix to show how to manually apply the model; and $\mathrm{b}$ ) the results for the discriminant analyses of the remaining competencies are given in tables $9 \mathrm{~A}$ through $12 \mathrm{~A}$ in the appendix. ${ }^{49}$ Finally, the capacity of the discriminant models adjusted for each IL competency was obtained, although the discriminating power of the models is visibly lower for competencies c1: using printed sources of information, c20: communicating in public, and c22: writing a document, as no significant differences were found between the degree programs with regard to the learning style in these competencies ${ }^{50}$ (see table $13 \mathrm{~A}$ in appendix).

Summary of Results

$\square \quad$ Directed learning is preferred for the four IL competency categories: searching, evaluation, processing, and communication-dissemination. The preference is higher in the categories of searching and evaluation.

$\square$ Autonomous learning students show higher belief-in-importance levels; self-efficacious ones prefer the directed style. 
- Audiovisual communication, education, and journalism students prefer autonomous learning.

- Information science and psychology students prefer the directed learning style.

- Statistically different profiles by degree program were not found in the competencies c1: using printed sources of information, c20: communicating in public, and c22: writing a document. (Here, students prefer directed style.)

- Within the searching category: Students show a greater preference for the autonomous style in c6: searching for and retrieving Internet information (advanced searches) and c7: using informal electronic sources of information (blogs, etc.). A higher percentage of women than men report this preference. For the remaining competencies, men generally display a preference for the directed learning style, especially in c4: using electronic sources of secondary information (databases, etc.) and c5: knowing the terminology of your subject.

- In the evaluation category, the autonomous style is lightly preferred only for c12: determining whether an information resource is updated.

- In the processing category, the higher preferences for the autonomous style are found for c14: schematizing and abstracting information and c19: installing computer programs.

$\square$ Within the communication-dissemination category, students clearly declare a preference for an autonomous learning style in c25: creating academic presentations (PowerPoint, etc.) and c26: disseminating information on the Internet (webs, blogs, etc.).

- Statistically significant differences regarding gender were found only in five competencies: c4: using electronic sources of secondary information, c5: knowing the terminology of your subject, c16: using database managers, c18: handling statistical programs and spreadsheets, and c19: installing computer programs.

$\square \quad$ The source of preferred learning can be predicted from belief-in-importance and self-efficacy levels from a discriminant analysis.

\section{Conclusions and Recommendations}

Results shed light on students' process of learning, which in turn may lead to different pedagogical approaches. When competencies are grouped, a higher preference for the directed learning style in the four IL categories (searching, evaluation, processing, and communicationdissemination of information) has been uncovered. Nevertheless, the analysis by degree program shows significant differences concerning preferred learning styles in most competencies.

A significant finding refers to the relationship uncovered between BI levels and learning styles: specifically, the greater belief-in-importance of a competency on the part of students, the larger the preference for autonomous learning. The same way, relationships between levels of SE and their learning styles were also observed, indicating that higher levels of selfefficacy are related to a greater preference for directed learning. This is the main advantage of the discriminant model used here on the base of BI and SE values, as it has the ability to predict learning styles. A better understanding of students' learning styles can reinforce and contribute to improving their academic performance, as faculty and instructors could redirect or strengthen such learning styles according to their better relationships with the students' beliefs and self-efficacy.

In addition, the model provides insight into students' information-seeking preferences, which can be useful for faculty and instructors aiming at promoting effective self-learning, as 
results can aid them in preparing online curricular materials and open educational resources associated with the autonomous learning style of the competencies prone to it. Likewise, the model can be of use for faculty and instructors in designing specific tools for face-to-face teaching of those IL competencies that are related to the directed learning style.

Knowing the opinion of faculty members about the importance of the most relevant learning scenarios (classroom, library, courses, and self-learning) in achieving the mastery of each IL competency is a matter of primary concern. In doing so, it would be possible to contrast these results with the information provided by the sample of SS students, thus knowing which learning resources are recommended and if they differ from the resources preferred by students. This would allow linking three important elements - experts' opinions, students' beliefs, and learning styles - of any learning process, which consequently could be applied to each discipline.

This pioneering evidence-based research has revealed key results on how an interuniversity group of students belonging to eight undergraduate degree programs within the field of Social Sciences perceives, behaves, and relates with regard to a series of IL competencies. The rigorous and comprehensive nature of the statistical model used makes it transferable and applicable to the analysis and evaluation of other key transversal competencies for students' global learning. 


\section{APPENDIX}

\begin{tabular}{|c|c|c|c|c|}
\hline \multicolumn{5}{|c|}{$\begin{array}{l}\text { TABLE 1A } \\
\text { Attitudes toward Directed Learning by Degree Program; Searching Category }\end{array}$} \\
\hline Searching & \multicolumn{2}{|c|}{ Higher trend toward directed learning } & \multicolumn{2}{|c|}{ Lower trend toward directed learning } \\
\hline c2 & \multicolumn{2}{|c|}{ Information Science } & \multicolumn{2}{|c|}{ Education } \\
\hline c3 & \multicolumn{2}{|c|}{ Information Science/ Psychology } & \multicolumn{2}{|c|}{ Audiovisual Communication/5-Journalism } \\
\hline c4 & \multicolumn{2}{|c|}{ Information Science/Psychology/Tourism } & \multicolumn{2}{|c|}{ Education } \\
\hline c5 & \multicolumn{2}{|c|}{ Information Science/Pedagogy/Psychology } & \multicolumn{2}{|c|}{ Education/Journalism } \\
\hline c6 & \multicolumn{2}{|c|}{ Information Science } & \multicolumn{2}{|c|}{$\begin{array}{l}\text { Audiovisual Comm./Education/Pedagogy / } \\
\text { Journalism/Psychology/Social Work /Tourism }\end{array}$} \\
\hline c7 & \multicolumn{2}{|c|}{ Information Science } & \multicolumn{2}{|c|}{ Audiovisual Communication/Social Work } \\
\hline c8 & \multicolumn{2}{|c|}{ Information Science } & \multicolumn{2}{|c|}{ Primary Education } \\
\hline \multicolumn{5}{|c|}{$\begin{array}{r}\text { TABLE } 2 A \\
\text { Attitudes toward Directed Learning by Degr }\end{array}$} \\
\hline Evaluation & \multicolumn{2}{|c|}{ Higher trend towards directed learning } & \multicolumn{2}{|c|}{ Lower trend towards directed learning } \\
\hline c9 & \multicolumn{2}{|c|}{ Information Science } & \multicolumn{2}{|c|}{$\begin{array}{l}\text { Audiovisual Comm../Education/Pedagogy / } \\
\text { Journalism/Psychology/Social Work /Tourism }\end{array}$} \\
\hline c10 & \multicolumn{2}{|c|}{ Education/Information Science/Tourism } & \multicolumn{2}{|c|}{ Journalism/Psychology } \\
\hline c11 & \multicolumn{2}{|c|}{ Information Science } & \multicolumn{2}{|c|}{$\begin{array}{l}\text { Audiovisual Comm../Education/Pedagogy / } \\
\text { Journalism/Psychology/Social Work /Tourism }\end{array}$} \\
\hline c12 & \multicolumn{2}{|c|}{ Information Science } & \multicolumn{2}{|c|}{ Audiovisual Communication/Journalism } \\
\hline c13 & \multicolumn{2}{|c|}{ Information Science/Psychology/Social Work } & \multicolumn{2}{|c|}{ Journalism } \\
\hline c14 & \multicolumn{2}{|c|}{ Information Science/ Education } & Psycho & logy \\
\hline & itude & $\begin{array}{l}\text { TABLE } \\
\text { s toward Directed Learning by De }\end{array}$ & ee Pro & gram; Processing Category \\
\hline Processing & Highe & er trend towards directed learning & Lower tr & end towards directed learning \\
\hline c15 & Inforr & mation Science/Education & Psycholc & ogy \\
\hline c16 & Inforr & mation Science/Tourism & Audiovis & sual Communication \\
\hline c17 & Inforr & mation Science & Audiovis & sual Communication/Education \\
\hline c18 & Peda & gogy/Psychology/Tourism & Audiovis & sual Communication \\
\hline c19 & Inforr & mation Science & Audiovis & sual Communication/ Journalism \\
\hline & & $\begin{array}{l}\text { TABLE 4/ } \\
\text { Attitudes toward Directed Learn } \\
\text { Communication-Dissemi }\end{array}$ & $\begin{array}{l}\text { A } \\
\text { ing by } \\
\text { ination }\end{array}$ & $\begin{array}{l}\text { Degree Program; } \\
\text { Category }\end{array}$ \\
\hline $\begin{array}{l}\text { Communica } \\
\text { Disseminati }\end{array}$ & ation- & Higher trend towards directed learning & & $\begin{array}{l}\text { Lower trend towards directed } \\
\text { learning }\end{array}$ \\
\hline C21 & & Education/Information Science/Pedag & ogy & Psychology \\
\hline c23 & & Psychology/Information Science/ Soci & ial Work & Education \\
\hline c24 & & $\begin{array}{l}\text { Information Science/ Audiovisual } \\
\text { Communication }\end{array}$ & & Psychology/ Social Work \\
\hline c25 & & Tourism/Pedagogy/Information Scienc & & $\begin{array}{l}\text { Audiovisual Communication/ } \\
\text { Journalism }\end{array}$ \\
\hline c26 & & Information Science/Education & & $\begin{array}{l}\text { Psychology/Audiovisual Comm./ } \\
\text { Social Work }\end{array}$ \\
\hline
\end{tabular}




\section{DISCRIMINANT ANALYSIS and Fisher's functions}

Mathematically, the discriminant analysis consists of a linear transformation of the explanatory variables to obtain functions with the capacity to classify other individuals.

The discriminant models ${ }^{39}$ for the selected competencies (one per category), c3 consulting and using electronic sources of primary information, c11 knowing the typology of scientific information sources, c14 schematizing and abstracting information, and c24 knowing the laws on the use of information and intellectual property, are listed in tables 5A-8A for student labeled "2" in table 8. Discriminant scores (one variable for each discriminant function in the solution) are also included to show how the model works.

\begin{tabular}{|c|c|c|c|c|c|c|c|c|c|c|c|c|}
\hline \multicolumn{13}{|c|}{$\begin{array}{l}\text { TABLE 5A } \\
\text { How the Discriminant Model Works for Competency c3; Discriminant Scores }\end{array}$} \\
\hline & \multicolumn{10}{|c|}{ Fisher's Standardized Function Coefficients } & \multirow[t]{2}{*}{ Score } & \multirow{2}{*}{$\begin{array}{l}\text { Assigned } \\
\text { group }\end{array}$} \\
\hline$c 3$ & BI & SE & $\begin{array}{l}\text { Audiovisual } \\
\text { Comm. }\end{array}$ & $\begin{array}{l}\text { Information } \\
\text { Science }\end{array}$ & Journalism & Pedagogy & Education & Psychology & $\begin{array}{l}\text { Social } \\
\text { Work }\end{array}$ & Constant & & \\
\hline Directed & 4.22 & 1.54 & 8.56 & 7.25 & 7.82 & 7.60 & 6.57 & 7.68 & 8.74 & -25.69 & 27.64 & $x$ \\
\hline Autonomous & 4.23 & 1.69 & 8.92 & 7.50 & 6.33 & 6.83 & 6.86 & 6.50 & 8.15 & -24.63 & 27.23 & \\
\hline Reported & 8 & 8 & 0 & 1 & 0 & 0 & 0 & 0 & 0 & & & \\
\hline
\end{tabular}

\begin{tabular}{|c|c|c|c|c|c|c|c|c|c|c|c|c|}
\hline \multicolumn{13}{|c|}{$\begin{array}{l}\text { TABLE 6A } \\
\text { How the Discriminant Model Works for Competency c11; Discriminant Scores }\end{array}$} \\
\hline & \multicolumn{10}{|c|}{ Fisher's Standardized Function Coefficients } & \multirow[t]{2}{*}{ Score } & \multirow{2}{*}{$\begin{array}{l}\text { Assigned } \\
\text { group }\end{array}$} \\
\hline$c 11$ & BI & SE & $\begin{array}{l}\text { Audiovisual } \\
\text { Comm. }\end{array}$ & $\begin{array}{l}\text { Information } \\
\text { Science }\end{array}$ & Journalism & Pedagogy & Education & Psychology & $\begin{array}{l}\text { Social } \\
\text { Work }\end{array}$ & Constant & & \\
\hline Directed & 2.45 & 0.93 & 8.25 & 8.66 & 7.22 & 7.83 & 7.76 & 8.22 & 8.67 & -15.99 & 18.78 & $x$ \\
\hline Autonomous & 2.56 & 0.79 & 8.28 & 8.99 & 6.21 & 7.63 & 7.53 & 8.54 & 9.02 & -14.03 & 16.97 & \\
\hline Reported & 8 & 7 & 0 & 1 & 0 & 0 & 0 & 0 & 0 & & & \\
\hline
\end{tabular}

\begin{tabular}{|l|c|c|c|c|c|c|c|c|c|c|c|}
\hline \multicolumn{1}{|c|}{ TABLE 7A } \\
\hline \\
\hline
\end{tabular}

\begin{tabular}{|l|c|c|c|c|c|c|c|c|c|c|c|}
\hline \multicolumn{1}{|c|}{ TABLE 8A } \\
\hline \\
\hline
\end{tabular}


From tables 5A-8A, this student would choose a directed learning style for competencies c11 and c24, while he would prefer an autonomous style for competencies c3 and c14 (as he is assigned to the group in which the highest score is obtained, highlighted in yellow).

To evaluate the efficiency of the discriminant models adjusted for each IL competency, classification tables were obtained using the Jackknife method or leave-one-out procedure. ${ }^{39}$ These tables provides the percentage of correctly classified cases and hence the discrimination capacity of the model. Results are included in table 13A.

Wilks' Lambda was used to assess the discriminating power of the functions. ${ }^{39}$ The scale ranges from 0 to 1 , where values closer to 0 indicate the greater discriminant power of the variables considered (see table 13A). The Wilks' Lambda values are quite high, thus demonstrating the presence of overlapping between groups. The transformed Wilks' Lambda values (chi square) are significant, indicating that the variances of each group are different and the discriminant analysis can be applied. ${ }^{40}$ In this study, we have considered the intra-group correlations and the previous probability of belonging to a specific group according to the size of the group. The nominal variable "degree program" was recoded into eight dichotomous dummy variables (one for each program). The dummy variables take the value of 1 if the student is in that program and zero otherwise. The discriminant functions obtained minimize the likelihood of classification error.

\section{SEARCHING}

\section{TABLE 9A}

Coefficients of the Discriminant Functions for the Competencies of the Searching Category

\begin{tabular}{|l|l|c|c|c|c|c|c|c|c|c|c|}
\hline & & BI Cat & $\begin{array}{c}\text { SE } \\
\text { Cat }\end{array}$ & $\begin{array}{c}\text { Audiovisual } \\
\text { Comm. }\end{array}$ & $\begin{array}{c}\text { Information } \\
\text { Science }\end{array}$ & Journalism & Pedagogy & Education & Psychology & $\begin{array}{c}\text { Social } \\
\text { Work }\end{array}$ & Constant \\
\hline c1 & Directed & 18.62 & 4.28 & 8.55 & 7.01 & 6.90 & 7.39 & 7.57 & 6.90 & 8.61 & -36.13 \\
\hline & Autonomous & 18.76 & 4.49 & 8.62 & 6.64 & 7.14 & 7.23 & 7.70 & 7.11 & 8.49 & -37.64 \\
\hline C2 & Directed & 6.83 & 2.23 & 8.48 & 6.41 & 7.81 & 7.77 & 8.80 & 8.06 & 8.77 & -15.64 \\
\hline & Autonomous & 7.01 & 2.22 & 8.39 & 4.95 & 7.32 & 7.51 & 9.19 & 7.48 & 8.17 & -16.61 \\
\hline c4 & Directed & 9.76 & 2.14 & 8.20 & 6.90 & 7.98 & 8.44 & 8.43 & 7.79 & 9.15 & -19.80 \\
\hline & Autonomous & 9.91 & 2.23 & 9.17 & 6.04 & 8.14 & 8.55 & 10.14 & 7.57 & 9.52 & -21.94 \\
\hline c5 & Directed & 21.99 & 2.73 & 8.08 & 8.59 & 8.46 & 9.13 & 8.20 & 6.67 & 8.33 & -39.17 \\
\hline & Autonomous & 22.16 & 2.54 & 8.81 & 8.47 & 9.36 & 9.13 & 9.07 & 6.58 & 8.48 & -41.39 \\
\hline c6 & Directed & 21.15 & 3.03 & 7.55 & 7.87 & 8.20 & 8.56 & 7.50 & 9.18 & 10.20 & -38.81 \\
\hline & Autonomous & 21.48 & 3.57 & 7.21 & 5.41 & 7.74 & 8.14 & 7.45 & 8.74 & 10.18 & -39.97 \\
\hline c7 & Directed & 7.58 & 4.51 & 8.82 & 8.73 & 7.85 & 8.30 & 8.76 & 10.50 & 9.35 & -20.98 \\
\hline & Autonomous & 7.37 & 5.13 & 9.56 & 7.36 & 8.26 & 8.21 & 8.71 & 10.81 & 10.07 & -21.09 \\
\hline c8 & Directed & 4.96 & 1.57 & 8.62 & 7.13 & 9.06 & 8.09 & 7.81 & 8.28 & 9.12 & -12.30 \\
\hline & Autonomous & 5.04 & 1.45 & 8.53 & 5.07 & 7.83 & 7.78 & 8.37 & 8.42 & 8.93 & -12.25 \\
\hline
\end{tabular}




\section{PROCESSING}

\begin{tabular}{|l|l|c|c|c|c|c|c|c|c|c|c|}
\hline \multicolumn{10}{|c|}{ TABLE 10A } \\
\hline & & Coefficients of the Discriminant Functions for the Competencies of the Processing Category \\
\hline & & $\begin{array}{c}\text { SE } \\
\text { cat }\end{array}$ & $\begin{array}{c}\text { Audiovisual } \\
\text { Comm. }\end{array}$ & $\begin{array}{c}\text { Information } \\
\text { Science }\end{array}$ & Journalism & Pedagogy & $\begin{array}{c}\text { Primary } \\
\text { Education }\end{array}$ & Psychology & $\begin{array}{c}\text { Social } \\
\text { Work }\end{array}$ & Constant \\
\hline C9 & Directed & 18.71 & 2.75 & 7.76 & 9.41 & 8.20 & 9.61 & 7.81 & 8.26 & 10.13 & -34.53 \\
\hline & Autonomous & 18.99 & 2.93 & 8.06 & 8.32 & 8.29 & 9.52 & 8.28 & 8.41 & 10.14 & -36.12 \\
\hline C10 & Directed & 28.78 & 3.27 & 7.30 & 7.92 & 7.94 & 7.16 & 7.10 & 5.94 & 8.67 & -50.07 \\
\hline & Autonomous & 28.71 & 3.67 & 7.43 & 7.80 & 8.76 & 7.03 & 7.02 & 6.62 & 8.80 & -51.52 \\
\hline C12 & Directed & 15.82 & 3.20 & 7.92 & 8.32 & 7.23 & 9.76 & 8.58 & 9.04 & 10.22 & -30.92 \\
\hline & Autonomous & 16.35 & 3.24 & 8.44 & 7.10 & 7.92 & 9.38 & 8.79 & 8.76 & 10.25 & -32.24 \\
\hline C13 & Directed & 12.94 & 1.71 & 6.62 & 7.46 & 6.35 & 6.17 & 7.68 & 6.88 & 7.47 & -23.70 \\
\hline & Autonomous & 13.22 & 1.40 & 6.85 & 6.66 & 7.11 & 6.03 & 7.89 & 6.64 & 7.16 & -25.00 \\
\hline
\end{tabular}

\section{EVALUATION}

\section{TABLE 11A}

Coefficients of the Discriminant Functions for the Competencies of the Evaluation Category

\begin{tabular}{|l|l|c|c|c|c|c|c|c|c|c|c|}
\hline & & BI cat & $\begin{array}{c}\text { SE } \\
\text { cat }\end{array}$ & $\begin{array}{c}\text { Audiovisual } \\
\text { Comm. }\end{array}$ & $\begin{array}{l}\text { Information } \\
\text { Science }\end{array}$ & Journalism & Pedagogy & $\begin{array}{c}\text { Primary } \\
\text { Education }\end{array}$ & Psychology & $\begin{array}{c}\text { Social } \\
\text { Work }\end{array}$ & Constant \\
\hline C15 & Directed & 16.32 & 6.36 & 8.33 & 7.73 & 7.88 & 6.86 & 6.62 & 8.18 & 9.71 & -35.79 \\
\hline & Autonomous & 16.44 & 6.62 & 8.30 & 7.24 & 8.06 & 6.99 & 6.37 & 8.71 & 9.98 & -37.48 \\
\hline C16 & Directed & 5.70 & 2.22 & 10.49 & 8.06 & 10.79 & 9.12 & 9.77 & 9.60 & 10.79 & -14.48 \\
\hline & Autonomous & 5.75 & 1.77 & 11.88 & 7.43 & 11.24 & 9.43 & 10.97 & 10.22 & 11.47 & -14.93 \\
\hline C17 & Directed & 4.71 & 1.82 & 8.90 & 7.90 & 9.46 & 8.51 & 8.42 & 8.47 & 9.27 & -12.05 \\
\hline & Autonomous & 4.87 & 1.29 & 9.51 & 6.89 & 9.05 & 8.21 & 9.07 & 8.45 & 9.13 & -11.95 \\
\hline C18 & Directed & 7.88 & 2.02 & 11.95 & 9.57 & 11.46 & 10.55 & 10.26 & 9.50 & 10.67 & -17.78 \\
\hline & Autonomous & 8.07 & 1.98 & 14.41 & 10.07 & 13.30 & 10.64 & 11.69 & 9.47 & 11.82 & -20.02 \\
\hline C19 & Directed & 6.16 & 2.56 & 7.97 & 9.10 & 9.79 & 9.51 & 9.17 & 10.37 & 10.45 & -16.08 \\
\hline & Autonomous & 6.50 & 3.32 & 9.17 & 7.83 & 10.56 & 9.30 & 9.49 & 11.04 & 10.98 & -17.71 \\
\hline
\end{tabular}

4. COMMUNICATION

TABLE12A

Coefficients of the Discriminant Functions for the Competencies of the Communication Category

\begin{tabular}{|l|l|c|c|c|c|c|c|c|c|c|c|}
\hline & & Bl cat & SE cat & $\begin{array}{c}\text { Audiovisual } \\
\text { Comm. }\end{array}$ & $\begin{array}{c}\text { Information } \\
\text { Science }\end{array}$ & Journalism & Pedagogy & $\begin{array}{c}\text { Primary } \\
\text { Education }\end{array}$ & Psychology & $\begin{array}{l}\text { Social } \\
\text { Work }\end{array}$ & Constant \\
\hline C20 & Autonomous & 49.44 & 2.73 & 9.23 & 12.32 & 7.47 & 9.34 & 7.70 & 9.12 & 11.78 & -80.70 \\
\hline & Directed & 49.86 & 2.94 & 9.68 & 12.81 & 7.45 & 9.49 & 7.74 & 9.73 & 11.84 & -82.73 \\
\hline C21 & Autonomous & 18.61 & 2.54 & 9.88 & 11.95 & 9.52 & 12.68 & 10.64 & 10.30 & 13.15 & -34.61 \\
\hline & Directed & 18.57 & 2.63 & 10.32 & 11.79 & 9.67 & 12.63 & 10.44 & 11.08 & 13.54 & -35.58 \\
\hline C22 & Autonomous & 68.22 & 2.96 & 7.29 & 9.79 & 8.08 & 10.64 & 7.30 & 6.14 & 11.58 & -109.18 \\
\hline & Directed & 68.17 & 2.98 & 7.74 & 9.93 & 8.43 & 10.53 & 7.53 & 6.41 & 11.82 & -109.97 \\
\hline C23 & Autonomous & 17.85 & 1.72 & 8.39 & 9.62 & 7.37 & 7.57 & 7.12 & 6.53 & 7.70 & -31.45 \\
\hline & Directed & 17.82 & 1.72 & 8.02 & 8.65 & 6.89 & 7.35 & 7.62 & 5.37 & 6.83 & -32.34 \\
\hline C25 & Autonomous & 18.57 & 14.31 & 11.32 & 11.79 & 10.54 & 7.81 & 8.50 & 11.05 & 10.42 & -52.32 \\
\hline & Directed & 18.66 & 14.69 & 12.30 & 11.94 & 11.43 & 7.88 & 8.77 & 11.83 & 10.74 & -53.44 \\
\hline C26 & Autonomous & 17.98 & 5.92 & 8.60 & 8.81 & 6.91 & 8.46 & 10.04 & 12.62 & 10.00 & -39.20 \\
\hline & Directed & 17.99 & 6.36 & 9.18 & 7.84 & 7.28 & 8.42 & 9.67 & 13.22 & 10.76 & -39.23 \\
\hline
\end{tabular}


5. RESULTS OF THE CLASSIFICATION

\begin{tabular}{|c|c|c|c|}
\hline \multicolumn{4}{|c|}{$\begin{array}{c}\text { TABLE 13A } \\
\text { Wilks' Lambda Values and Predictive Capacity of the Models }\end{array}$} \\
\hline Category & Competency & $\begin{array}{c}\text { Wilks' Lambda chi } \\
\text { (sig.) }\end{array}$ & $\begin{array}{c}\text { \% Correctly Classified } \\
\text { Cases (Jackknife) }\end{array}$ \\
\hline \multirow[t]{8}{*}{ Searching } & $\mathrm{C} 1$ & $0.688 /(0.028)^{*}$ & 68.5 \\
\hline & $\mathrm{C} 2$ & $0.651 /(0.000)$ & 77.5 \\
\hline & $\mathrm{C} 3$ & $0.501 /(0.000)$ & 73.7 \\
\hline & $\mathrm{C} 4$ & $0.693 /(0.000)$ & 81.4 \\
\hline & $\mathrm{C} 5$ & $0.576 /(0.000)$ & 85.1 \\
\hline & $\mathrm{C} 6$ & $0.509 /(0.000)$ & 81.2 \\
\hline & $\mathrm{C7}$ & $0.529 /(0.000)$ & 83.7 \\
\hline & $\mathrm{C} 8$ & $0.483 /(0.000)$ & 71.5 \\
\hline \multirow[t]{5}{*}{ Processing } & $\mathrm{C} 9$ & $0.557 /(0.000)$ & 67.5 \\
\hline & C10 & $0.562 /(0.000)$ & 71.1 \\
\hline & $\mathrm{C} 11$ & $0.561 /(0.000)$ & 78.2 \\
\hline & $\mathrm{C} 12$ & $0.535 /(0.000)$ & 73.1 \\
\hline & $\mathrm{C} 13$ & $0.466 /(0.000)$ & 85.9 \\
\hline \multirow[t]{6}{*}{ Evaluation } & C14 & $0.559 /(0.000)$ & 73.2 \\
\hline & C15 & $0.477 /(0.000)$ & 73.2 \\
\hline & $\mathrm{C} 16$ & $0.402 /(0.000)$ & 75.3 \\
\hline & $\mathrm{C} 17$ & $0.512 /(0.000)$ & 74.0 \\
\hline & C18 & $0.473 /(0.000)$ & 78.8 \\
\hline & C19 & $0.492 /(0.000)$ & 90.0 \\
\hline \multirow{7}{*}{$\begin{array}{l}\text { Communication- } \\
\text { Dissemination }\end{array}$} & $\mathrm{C} 20$ & $0.580 /(0.000)$ & 66.3 \\
\hline & $\mathrm{C} 21$ & $0.476 /(0.000)$ & 77.6 \\
\hline & $\mathrm{C} 22$ & $0.445 /(0.524)^{*}$ & 66.0 \\
\hline & $\mathrm{C} 23$ & $0.547 /(0.000)$ & 87.1 \\
\hline & $\mathrm{C} 24$ & $0.514 /(0.000)$ & 82.2 \\
\hline & $\mathrm{C} 25$ & $0.569 /(0.000)$ & 78.4 \\
\hline & C26 & $0.552 /(0.000)$ & 87.6 \\
\hline
\end{tabular}




\section{Notes}

1. Karl Popper, The Logic of Scientific Discovery (New York, NY : Basic Books, 1959); Thomas S. Kuhn, The Structure of Scientific Revolutions (Chicago, IL: University of Chicago Press, 1962).

2. Carol C. Kuhlthau, "Developing a Model of the Library Search Process: Investigation of Cognitive and Affective Aspects," Reference Quarterly 28, no. 2 (1988): 232-42.

3. ACRL Board, Framework for Information Literacy for Higher Education (2016); ALA, Information Literacy Competency Standards for Higher Education (2000), available online at http://www.ala.org/acrl/standards/ilframework [accessed 19 January 2019].

4. Alison J. Head and Michael B. Eisenberg, "Lessons Learned: How College Students Seek Information in the Digital Age, Project Information Literacy First Year Report with Student Survey Findings" (2009), available online at https://www.projectinfolit.org/uploads/2/7/5/4/27541717/pil_fall2009_finalv_yr1_12_2009v2.pdf [accessed 19 January 2019].

5. Christine Bruce, Sylvia Edwards, and Mandy Lupton, "Six Frames for Information Literacy Education: A Conceptual Framework for Interpreting the Relationships between Theory and Practice," Innovation in Teaching and Learning in Information and Computer Sciences 5, no. 1 (Jan. 2006): 1-18, available online at https://www. tandfonline.com/doi/abs/10.11120/ital.2006.05010002 [accessed 19 January 2019].

6. Alanna Ross and Christine Furno, "Active Learning in the Library Instruction Environment: An Exploratory Study," portal: Libraries and the Academy 11, no. 4 (2011): 953-70, available online at http://muse.jhu.edu/ content/crossref/journals/portal_libraries_and_the_academy/v011/11.4.ross.html [accessed 19 January 2019]; ACRL, "Characteristics of Information Literacy Programs That Illustrate Best Practices: A Guideline" (2003), available online at http://www.ala.org/acrl/standards/characteristics [accessed 10 January 2019]; S. Bodi, "Teaching Effectiveness and Bibliographic Instruction: The Relevance of Learning Styles," College E Research Libraries 51, no. 2 (1990): 113-19; D. Holt, I. Smissen, and S. Segrave, "New Students, New Learning, New Environments in Higher Education: Literacies in the Digital Age," in Who's Learning? Whose Technology? Proceedings [of] the 23rd Annual Conference of the Australasian Society for Computers in Learning in Tertiary Education (Sydney, Australia: Sydney University Press, 2006).

7. Annemaree Lloyd, "Information Literacy as a Socially Enacted Practice: Sensitising Themes for an Emerging Perspective of People-in-Practice," Journal of Documentation 68, no. 6 (2012): 772-83, doi:10.1108/00220411211277037.

8. Geoff Walton and Jamie Cleland, "Information Literacy. Empowerment or Reproduction in Practice? A Discourse Analysis Approach," Journal of Documentation 73, no. 4 (2017): 582-94, doi:10.1108/JD-04-2015-0048.

9. Louise Limberg et al., "What Matters? Shaping Meaningful Learning through Teaching Information Literacy," Libri 58, no. 2 (2008): 82-91.

10. Avril Patterson, "A Needs Analysis for Information Literacy Provision for Research: A Case Study in University College Dublin," Journal of Information Literacy 3, no. 1 (2009): 5-18; B. Roszkowski and G. Reynolds, "Assessing, Analyzing, and Adapting: Improving a Graduate Student Instruction Program through Needs Assessment," Behavioral \& Social Sciences Librarian 32, no. 4 (2013): 224-39.

11. T. Alqudsi-Ghabra and E. Al-Dousari, "Internet Use among Incoming Undergraduate Students of Kuwait University," Journal of Information and Knowledge Management 13, no. 2 (2014); E.E. Baro and B. Fyneman, "Information Literacy among Undergraduate Students in Niger Delta University," Electronic Library 27, no. 4 (2009): 659-75; S. Lin, T.H. Shih, and R. Lu, "ICT Proficiency and Gender: A Validation on Training and Development," International Journal of Technology and Design Education 23, no. 2 (2013): 179-90.

12. S. Rehman and S. Al Awadhi, "Value of a Structured Information Literacy Course: A Case Analysis," Malaysian Journal of Library and Information Science 18, no. 1 (2013): 27-37.

13. Mitchell Ross, Helen Perkins, and Kelli Bodey, "Information Literacy Self-Efficacy: The Effect of Juggling Work and Study," Library E Information Science Research 35, no. 4 (Oct. 2013): 279-87, available online at http:// linkinghub.elsevier.com/retrieve/pii/S0740818813000686 [accessed 19 January 2019].

14. Serkan Dincer and Yunis Sahinkayasi, "A Cross-Cultural Study of ICT Competency, Attitude and Satisfaction of Turkish, Polish and Czech University Students," Turkish Online Journal of Educational Techology 10, no. 4 (2011): 31-38.

15. Susie Andretta, "Phenomenography: A Conceptual Framework for Information Literacy Education," Aslib Proceedings 59, no. 2 (2007): 152-68, available online at www.emeraldinsight.com/10.1108/00012530710736663 [accessed 19 January 2019]; Stuart Boon, Bill Johnston, and Sheila Webber, "A Phenomenographic Study of English Faculty's Conceptions of Information Literacy," Journal of Documentation 63, no. 2 (2007): 204-28, available online at www.emeraldinsight.com/10.1108/00220410710737187 [accessed 19 January 2019]; Melissa Gross and Don Latham, "Addressing below Proficient Information Literacy Skills: Evaluating the Efficacy of an Evidence-Based 
Educational Intervention," Library \& Information Science Research 35 (2013): 181-90.

16. Marc Forster, "Developing an 'Experience Framework' for an Evidence-Based Information Literacy Educational Intervention," Journal of Documentation 72, no. 2 (2016): 306-20, doi:10.1108/JD-06-2015-0077.

17. Raziye Demiralay and Sirin Karadeniz, "The Effect of Use of Information and Communication Technologies on Elementary Student Teachers' Perceived Information Literacy Self-Efficacy," Educational Sciences: Theory and Practice 10, no. 2 (2010): 841-51; M. Gross and D. Latham, "What's Skill Got to Do with It? Information Literacy Skills and Self-Views of Ability among First-Year College Students," Journal of the American Society for Information Science and Technology 63, no. 3 (2012): 574-83; Melissa Gross and Don Latham, "Attaining Information Literacy: An Investigation of the Relationship between Skill Level, Self-Estimates of Skill, and Library Anxiety," Library E Information Science Research 29 (2007): 332-53; S.S. Kurbanoglu, B. Akkoyunlu, and A. Umay, "Developing the Information Literacy Self-Efficacy Scale," Journal of Documentation 62, no. 6 (2006): 730-43; Maria Pinto, "Design of the IL-HUMASS Survey on Information Literacy in Higher Education: A Self-Assessment Approach," Journal of Information Science 36, no. 1 (2010): 86-103; Maria Pinto et al., "Designing and Implementing Web-Based Tools to Assess Information Competences of Social Science Students at Spanish Universities," in Worldwide Commonalities and Challenges in Information Literacy Research and Practice, eds. Serap Kurbanoglu et al. (Istanbul: Springer, 2013), 443-49; Ross and Furno, "Active Learning in the Library Instruction Environment"; Yasemin Kocak Usluel, "Can ICT Usage Make a Difference on Student Teachers' Information Literacy Self-Efficacy," Library \& Information Science Research 29, no. 1 (Mar. 2007): 92-102, available online at http://linkinghub.elsevier.com/retrieve/pii/ S0740818807000102 [accessed 19 January 2019].

18. Afrodite Malliari, Stella Korobili, and S. Zapounidou, "Exploring the Information Seeking Behavior of Greek Graduate Students: A Case Study Set in the University of Macedonia," International Information \& Library Review 43, no. 2 (2011): 79-91.

19. Gerhard Blickle, "Personality Traits, Learning Strategies, and Performance," European Journal of Personality 10, no. 5 (1996): 337-52.

20. Ference Marton and Roger Säljö, “On Qualitative Differences in Learning," British Journal of Educational Psychology 46 (1976): 115-27.

21. David Kolb, Experiential Learning: Experience as the Source of Learning and Development (Englewood Cliffs, NJ: Prentice Hall, 1984).

22. Heather Sanderson, "Using Learning Styles in Information Literacy: Critical Considerations for Librarians," Journal of Academic Librarianship 37, no. 5 (2011): 376-85.

23. Robert J. Sternberg, Thinking Styles (Cambridge, UK: Cambridge University Press, 1997).

24. Li-Fang Zhang, "Thinking Styles and Modes of Thinking: Implications for Education and Research," Journal of Psychology 36, no. 3 (2002).

25. Li-Fang Zhang, Robert J. Sternberg, and Jieqiong Fan, "Revisiting the Concept of 'Style Match,'” British Journal of Educational Psychology 83, no. 2 (2013): 225-37.

26. Sanderson, "Using Learning Styles in Information Literacy"; Jannica Heinström, "The Impact of Personality and Approaches to Learning on Information Behaviour," Information Research 5, no. 3 (2000); J. Heinström, "Five Personality Dimensions and Their Influence on Information Behavior," Information Research 9, no. 1 (2003), available online at http://www.informationr.net/ir/9-1/paper165.html [accessed 19 January 2019]; Jannica Heinström, "Fast Surfing, Broad Scanning and Deep Diving: The Influence of Personality and Study Approach on Students' Information-Seeking Behavior," Journal of Documentation 61, no. 2 (2005): 228-47; Jannica Heinström, "Fast Surfing for Availability or Deep Diving into Quality-Motivation and Information Seeking among Middle and High School Students," Information Research 11, no. 4 (2006), available online at http://www.informationr.net/ ir/11-4/paper265.html [accessed 19 January 2019]; Richard N. Landers and John W. Lounsbury, "An Investigation of Big Five and Narrow Personality Traits in Relation to Internet Usage," Computers in Human Behavior 22, no. 2 (2006): 283-93.

27. Sharon Markless and David Streatfield, "Three Decades of Information Literacy: Redefining the Parameters," in Change and Challenge: Information Literacy for the 21st Century, ed. Susie Andretta (Adelaide, Australia: Auslib Press, 2007), 17.

28. Rae-Anne Diehm and Mandy Lupton, "Approaches to Learning Information Literacy: A Phenomenographic Study," The Journal of Academic Librarianship 38, no. 4 (2012): 217-25, available online at www.sciencedirect.com/ science/article/pii/S0099133312000754 [accessed 19 January 2019].

29. Judith Palmer, "Scientists and Information: II. Personal Factors in Information Behaviour," Journal of Documentation 47, no. 3 (1991): 254-75.

30. Sheila Webber, Stuart Boon, and Bill Johnston, "A Comparison of UK Academics' Conceptions of Information Literacy in Two Disciplines: English and Marketing," Library and Information Research 29, no. 93 (2005): 4-15, available online at https://www.lirgjournal.org.uk/index.php/lir/article/view/197/242 [accessed 19 January 2019]. 
31. Claire McGuinness, "What Faculty Think: Exploring the Barriers to Information Literacy Development in Undergraduate Education," Journal of Academic Librarianship 32, no. 6 (Nov. 2006): 573-82, available online at http://linkinghub.elsevier.com/retrieve/pii/S0099133306001066 [accessed 19 January 2019].

32. Emma Coonan, "Teaching Learning: Perceptions of Information Literacy," Arcadia Programme. University of Cambridge (2011), available online at https://www.repository.cam.ac.uk/bitstream/handle/1810/244637/theory. pdf?sequence=1\&isAllowed=y [accessed 19 January 2019].

33. Philip C. Candy, Linking Thinking: Self-Directed Learning in the Digital Age (Canberra: Australian Government, Department of Education, Science and Training, 2004).

34. Pinto, "Design of the IL-HUMASS Survey on Information Literacy"; Maria Pinto, "An Approach to the Internal Facet of Information Literacy Using the IL-HUMASS Survey," Journal of Academic Librarianship 37, no. 2 (2011): 145-54.

35. Maria Pinto, "Assessing Disciplinary Differences in Faculty Perceptions of Information Literacy Competencies," Aslib Journal of Information Management 68, no. 2 (2016): 227-47.

36. Maria Pinto and Rosaura Fernandez-Pascual, "Exploring LIS Students Beliefs in Importance and SelfEfficacy of Core Information Literacy Competencies," College \& Research Libraries 77, no. 6 (2016): 703-26, doi:10.5860/ crl.77.6.703.

37. Andretta, "Phenomenography," 152-68; Diehm and Lupton, "Approaches to Learning Information Literacy"; Forster, "Developing an 'Experience Framework' for an Evidence-Based Information Literacy Educational Intervention," 306-20.

38. Pinto, "Design of the IL-HUMASS Survey on Information Literacy."

39. Pinto, "An Approach to the Internal Facet of Information Literacy Using the IL-HUMASS Survey"; Maria Pinto et al., "Attitudes toward Information Competency of University Students in Social Sciences," portal: Libraries and the Academy 16, no. 4 (2016): 737-61.

40. Pinto and Fernandez-Pascual, "Exploring LIS Students Beliefs in Importance and Self-Efficacy of Core Information Literacy Competencies"and Self-Efficacy (SE; Maria Pinto and Rosaura Fernandez-Pascual, "A Diagnosis of the Levels of Information Literacy Competency among Social Sciences Undergraduates," portal: Libraries and the Academy (in press, 2017).

41. R.A. Johnson and D.W. Wichern, Applied Multivariate Statistical Analysis (Upper Saddle River, NJ: Pearson Education Inc., 2007); B.F. Manly, Multivariate Statistical Methods: A Primer (New York, NY: Chapman \& Hall/CRC, 2005); J.P. Stevens, Applied Multivariate Statistics for the Social Sciences, 5th ed. (New York, NY: Routledge, 2009).

42. J. Hair et al., Multivariate Data Analysis: A Global Perspective, 7th ed. (Upper Saddle River, NJ: Pearson Prentice Hall, 2010); M. Savic, D. Brcanov, and S. Dakic, "Discriminant Analysis: Applications and Software Support," Management Information Systems 3, no. 1 (2008): 29-33; S. Sharma, Applied Multivariate Techniques (Hoboken, NJ: John Wiley and Sons, 1998).

43. Janet Hyde, Elizabeth Fennema, and Susan Lamon, "Gender Differences in Mathematics Performance: A Meta-Analysis," Psychological Bulletin 107, no. 2 (1990): 139-55.

44. W.H. Kruskal and W.A. Wallis, "Use of Ranks in One-Criterion Variance Analysis," Journal of the American Statistical Association 47, no. 260 (1952): 583-621.

45. Rita Dunn, Kenneth Dunn, and Gary E. Price, “Diagnosing Learning Styles: A Prescription for Avoiding Malpractice Suits," Phi Delta Kappan 58, no. 5 (1977): 418-20.

46. Christopher Allinson and John Hayes, "The Learning Style Questionnaire: An Alternative to Kolb's Inventory," Journal of Management Studies 25, no. 3 (1988): 269-81.

47. S. Cheng, L.F. Zhang, and X. Hu, "Thinking Styles and University Self-Efficacy Among Deaf, Hard-ofHearing, and Hearing Students," Journal of Deaf Studies and Deaf Education 21, no. 1 (2016): 44-53.

48. Hair et al., Multivariate Data Analysis: A Global Perspective.

49. Savic, Brcanov, and Dakic, "Discriminant Analysis."

50. John Tukey, "Bias and Confidence in Not-Quite Large Samples," Annals of Mathematics and Statistics 29, no. 2 (1958): 614. 